\title{
Taboo Expression in Kinship of Karo Tribe
}

\author{
Karisma Erikson Tarigan ${ }^{1}$, Mhd. Pujiono ${ }^{2}, \mathrm{Akmal}^{3}$, Ernita Daulay ${ }^{4}$ \\ 1 erick_tarigan2006@yahoo.com \\ 2 mhd.pujiono@usu.ac.id \\ 3 akmal.shafa@gmail.com \\ 4 ernitadaulay@student.usu.ac.id
}

Fakultas Ilmu Budaya, Universitas Sumatera Utara, Indonesia

\begin{abstract}
Sociolinguistic viewed cultural norm in terms of taboo to create boundaries and it was agreed upon by the community although it was not written down. Karo people who had cultural awareness belived that language taboos should be avoided for peaceful coexistence in society. This research was aimed to reveal the meaning of Taboo in Karo tribe. This research employed a descriptive qualitative method, was to obtain the description of Karo taboo cultures. The sample of this study was in the village of Padang Bulan Selayang, District of Medan Selayang, North Sumatra, Indonesia. The results showed that taboo in direct communication for three types of relationships or for six people, namely between 'mami' (daughter-in-law) with 'kela' (son-in-law), 'bengkila' (male-in-law) with 'permain' (daughter-in-law), and 'turangku' (husband of husband's sister/brother) with 'turangku' (wife of wife's brother/sister) in the form of rebu walking (Rebu Perdalan), rebu face to face (Rebu Sia-alan), rebu one seat (Rebu sada Amak), and rebu shake hands (Rebu Rebu La banci Sisalamen). The meaning of taboo classified into damaging kinship ethics, violate politeness, severing ties of friendship, and degrading culture and ancestors.
\end{abstract}

Keywords: Taboo, Karo Tribe, Sociolinguistic

\section{Introduction}

Every cultured ethnic group can certainly have things that are considered taboo. This belief system affects all factors of human life including health, ritual, marriage, caste, culture, social, religion, conversation, and so on. Taboo means to forbid or forbidden. It is an unwritten law of tribal society and whose violation is not dealt with by society (Mhaiske et al, 2016). Taboo (in Karo "rebu”) is a rule created by the ancestors on the basis of their understanding of the phenomena that occur in their society, both in public relations with other creatures, with nature, and with fellow humans. Taboos are related to prohibitions in culture, based on social, magical and religious reasons, so that people who violate taboos are believed to be able to cause themselves and or their families to receive social sanctions from the community, magical sanctions from an evil spirit entity, or religious sanctions from the Creator.

Taboos have also been widely studied from a sociolinguistic point of view. This science looks at the meaning of the use of language associated with social norms that apply to a society. Among these reviews of taboos from a sociolinguistic point of view is the study of Qanbar (2011), which investigates language taboos in Yemeni society in relation to the social context of their use and the socio-cultural factors that influence their use. Qanbar explains the strategy used by Yemeni speakers to avoid the use of taboos, namely through various types of exchanging taboo words with words that are more acceptable to the community such as using 
jargon terms, word order, euphemisms, antonyms, metaphorical expressions, and using Arab standard language terms. Laksana (2009), in his research results mentions that there is the term abstinence (abstinence) which also means 'prohibition' as well as taboo; but both show differences in terms of taboo, violations cause violators to be plagued, while in 'abstinence' violators are only subject to physical sanctions or social sanctions.

Karo people show a very strong taboo in direct communication for three types of relationships or for six people, namely between 'mami' (daughter-in-law) with 'kela' (son-in-law), 'bengkila' (male-in-law) with 'permain' (daughter-in-law), and 'turangku' (husband of husband's sister/brother) with 'turangku' (wife of wife's brother/sister). In Karo language, this type of taboo is called 'rebu.' In addition, the Karo people are also considered taboo to mention certain names, such as the names of parents, uncles, aunts, in-laws, grandfathers, grandmothers, and older relatives in the family tree.

Research on taboos that are still alive among the Karo people to date is important for the following reasons. In today's modern era, it is undeniable that there is a process of cultural uprooting from the community that owns the culture itself. This also happens to the Karo people, so that many people, especially the younger generation, do not understand their customs anymore - including things that are busy-correctly. Many of them consider that the taboo in their culture is only limited to swear words that can threaten the peace of their society. In fact, communication in the relationship can be done using a third person projection. If this continues continuously, their customs may gradually disappear completely, resulting in the destruction of society morally. An example is the limitation of communication between mother-in-law and son-in-law or father-in-law and daughter-in-law. In order for communication between in-laws and daughter-in-law to work well, a mediator must be used. The origin of Rebu in the Karo community is the occurrence of misunderstandings between the son-in-law and the in-laws, which causes disputes in the family. Rebu's goal is to prevent misunderstandings between families from arising.

The results of this study are expected to contribute knowledge that is beneficial to the academic community and also cultural observers who have special attention to language taboos, especially in the Karo language. From the description of the background above, it can be stated that the main problem of this research is 'What is the meaning of taboo in the Karo people's view?'

\section{Theoretical Framework}

\subsection{Sociolinguistic}

Sociolinguistic is the study of language use and the constitutions of social relations (Heinrich \& Ohara, 2019). Sociolinguistic is concerned with investigating with the relationships between language and society with the goal being a better understanding of the structure of language and of how languages function in communication, the goal of sociology in a language is trying to discover how social structure can be better understood through the study of language (Wardhaugh, 2009).

One of the central concepts in sociolinguistic is the context: context is not only the local textual or social setting context, but also the larger social and cultural background in which language operates. Thus, sociolinguistics also investigates how cultural values and interaction norms affect language use for speakers within a certain cultural group. Its focus is the speech community and asks the questions of what a speaker needs to know to communicate appropriately within a particular speech community (Pan et al, 2019). Cultural sociology means the form of behavior must be seen as governed by sets of sanctioned norms, or ideologies, and the character of these norms is moral (Bloomaert, 2018).

Every society has its own particular taboo act and taboo words (Zyngier \& Chesnovoka, 2007). In sociological literature, taboo can prevent social conflicts and have the function to mark 'all those phenomena in a society which could be potentially dangerous for its members.' It adds to the stability of societies groups and has protective function. Taboo cover sore pains in sociolinguistic or potentially painful spots of a community and thereby ensure the survival of the groups and its members (Hernandez, 2009). 


\subsection{Taboo}

The English word 'taboo' derives from Tongan 'tabu'. It entered the language towards the end of the 18th century. It refers to forbidden behavior and relates into tradition of etiquette and are intimately linked with social organization (Allan, 2010). Taboos normally arise from social restrictions on individual behavior that can cause discomfort, harm or injure oneself or others (Allan, 2019). Taboo is now used loosely of any social indiscretion or word that ought to be avoided since it is strictly speaking (Hughes, 2015).

A taboo designates everything that is taken away from common usage, thus prohibited and inviolable; this could concern objects, places, actions, humans, or animals. Ethnographic enquiries reveal that such interdictions exist in all cultural systems (Mani \& Weiss, 2013). Taboo means the avoidance of a specific behavior for fear of harm and it might have horrendous society-wide consequences, examples are incest, culturally defined but universally forbidden, or severe forms of sacrilege (Birx, 2006). Taboos were put in place as warnings to control community members from engaging in specific prohibited practices agreed upon by particular community while proverbs were meant to serve as warnings or as words of encouragement to members of a particular member of community. Taboos are believed to have been introduced to regulate the moral order of society. Taboos always appear strict, threatening, and intimidating, but the main purpose was to have a society that was obedient to the values of society (Kazeroony et al, 2019).

Because the taboo meaning explored is a cultural meaning, this meaning is not based on individual understanding, but must be based on the collective understanding of the community (Congress \& Chang-Muy, 2008). Taboo integrally contains rules and specific cultural beliefs, namely what is appropriate and inappropriate in relationships that function as community control in social interactions (Rossi, 1974).

\subsection{Context}

Verbal communication was the primary medium of information exchange between participants. It can be characterized in terms of its clarity of message and the directness of intended recipient (Marini, 2018). Context is a world filled with people producing utterances, people who have social, cultural, and personal identities, knowledge, beliefs, and who interact with one another in various socially and culturally defined situations (Gonzales, 2004).

Speaker and listener engages in a context. The context of speech also includes the social expectation and cultural rules that come into play when speakers and listeners interact (German et al, 2016). Broadly speaking, the context consists of two kinds, namely the context of the situation and the context of the atmosphere. Situation context, what is meant by situational context is the immediate environment in which the text actually functions. Or in other words, the context of the situation is the whole environment, both the speech environment (verbal) and the environment in which the text is produced (spoken or written). The context of the situation consists of (1) the field of discourse, (2) the involvement of the discourse, and (3) the mode/means of discourse. The field of discourse refers to the social activities that are going on or what the participants are really busy with. Discourse participants refer to the people who take part, the nature of the participants, their position and roles, what kinds of role relationships exist between the participants. Means of discourse refers to the part of language that is being played out in a situation, including the chosen channel, whether spoken or written (Halliday \& Hasan,1985).

The characteristics of context that are relevant in the context of a situation are:

a. Setting and scene, namely background and atmosphere. The setting is more physical, which includes the place and time of the speech. While the scene is a psychological setting that refers more to the psychological atmosphere that accompanies the speech.

b. Participants, speech participants, namely people who are involved in the conversation, either directly or indirectly. Matters related to participants, such as age, education, social background, and so on are also of concern. 
c. Ends, results, namely the results or responses of a conversation that is expected by the speaker (ends as outcomes), and the ultimate goal of the conversation itself (ends in view goals).

d. Act sequence, message/mandate, consisting of message form and message content.

e. Key, includes the manner, tone, attitude, or spirit in a conversation. The spirit of conversation, for example: serious, relaxed, friendly, and so on.

f. Instrumentalities or means, namely a means of conversation. It means by what medium the conversation is conveyed. For example: verbally, in writing, letters, radio, and so on.

g. Norms, refers to norms or rules that limit conversation. For example, what can be said and not, how to talk about it: smooth, rough, open, and so on.

h. Genres or types, namely types or forms of discourse. This directly refers to the type of discourse delivered. For example: telephone, newspaper, poetry, lecture, and so on (Bauman \& Sherzer, 1989).

\section{Research Method}

This research employed a descriptive qualitative method, since it mainly concerned with describing the nature or condition and the degree in the detail of present situation. The aim of descriptive research was to obtain an accurate profile of the people, events, or situations (Chaudary, 2011). Descriptive qualitative was focused on the description of cultures or groups and aims to uncover patterns and typologies (Daymon \& Holloway, 2010).

The sample of this study was in the village of Padang Bulan Selayang, District of Medan Selayang, North Sumatra, Indonesia. This district was chosen for two reasons, namely: (1) it had been the center of Karo culture since its existence until now; and (2) a place inhabited by the largest number of existing Karo people. These two reasons convinced the writers that the determination of the chosen location had met the needs, so that what was sought in this study could be obtained easily and completely, and the data collected was considered to be able to represent the verbal expression of the entire existing Karo community.

The data collection method in qualitative researches were in-depth interviews, focus groups, and observations (Aveyard, 2018). Data analysis includes analysis during data collection, data reduction as a selection process, focusing on simplification, abstracting, transforming rough data that emerges from field notes, presenting data, and drawing conclusions/verification (Brooks \& Arnold, 2013). The data analysis technique used in this study is a qualitative analysis technique with the stages (1) Selecting data to select data that are truly valid, (2) describing all taboo language data that are truly valid, (3) classifying data taboo language in the Karo community based on the context, and (4) analyzing the data to draw conclusions.

\section{Results and Discussions}

The results of this study contain answers to research questions, namely classifying and explaining taboo expressions in the Karo language. The presentation was carried out by describing the forms of taboo expressions lexically and classifying them based on existing criteria, analyzing the process of taboo occurrences, and finding formulas, structures or rules for taboo occurrences in the Karo language.

Basically the term kinship in every tribe in the world had a universal cultural system, which started from two families who joined into one family through a marriage bond. In Karo culture, marriage did not merely unite two nuclear families through a sacred spiritual bond between a man from one nuclear family and a woman from another nuclear family, but also created a barrier or prohibition in communication. This limitation or prohibition on communicating began with the mukul event, which was a traditional ritual carried out at the home of the groom's parents at night after the party marriage. Karo people were considered taboo to communicate directly in three kinship relationships, namely bengkila with permain, ertuangku (turangku with turangku), and mami with keila. 
4.1 Bengkila with Permain

Rules in Karo language indicate taboo to communicate verbally directly between the workshop and the game. In Karo language, the word bengkila has two meaning: (1) husband of father's sister; and (2) father of husband/male-in-law. In terms of taboo, the workshop referred to refers to: on meaning (2). Bengkila is husband's father-in-law/father, and permain is daughter-in-law/son's wife.
(1) Bengkila : Kuja kam e permen?
INTROG 2Tg PART permain
Where are you going, permain?
Permain : Ku kede bengkila, kai kin?
PREP shop bengkila INTROG PART
To the shop bengkila, what's up?

The short conversation between bengkila and permain showed a communication that was considered to violate the rules of language. The bengkila question which was intentionally and directly addressed to permain, and permain who directed his speech directly to answer the question has violated the Karo language rules. In this case, both individuals had violated language ethics because they did not use something as an intermediary in their conversation.

\subsection{Turangku with turangku}

Communication between turangku and turangku without a third party intermediary also showed a violation of language rules in Karo culture. This could be seen in sentence (2) below:

(2) Turangku (A): Kuja idahndu silihndu ndai, Turangku?

INTROG nampak.2Tg.SOP ipar.2Tg.SOP DEM turang.1Tg

Where was my brother-in-law, Turangku (sister-in-law's husband)?

Turangku (B): $\quad$ I...e la kueteh da turangku, pakjulun

INTER DEM NEG 1Tg.tahu PART turang.1Tg PREP hulu

ndai ia kuidah, turangku

DEM 3Tg 1Tg.nampak turang.1Tg

I don't know turangku (brother-in-law's wife), I saw him that way, turangku.

$\begin{array}{ll}\text { Eida : } & \begin{array}{l}I . . \\ \text { siperkuanen }\end{array} \\ & \text { INTER 2Jm DEM wrong DEM INTROG talking to each other } \\ & \text { kena ras turangkuna. } \\ & \text { 2Jm KONJ turang.1Tg.3Tg } \\ & \text { You are wrong, why are you talking when you ber-turang }\end{array}$

Turangku (A) was a woman and turangku (B) was a man. In Karo culture, a relationship called berturangku was caused by two different categories, namely: (1) the existence of a relationship through husband or wife; and (2) the existence of a relationship with the besan through child marriage. It could be seen that turangku (A) was 'wife's brother's wife', and turangku (B) was 'husband's sister's husband.'

\subsection{Mami with Keila}

As it was the prohibition on language in the two types of kinship above, mami was also taboo to communicate directly with her daughter-in-law, who was called keila. In form, Mami and Keila were basic 
lexical and were included in the noun or noun category because they were names of kinship. Mami was the daughter-in-law/mother of the wife, while Keila was the son-in-law/husband of the daughter.

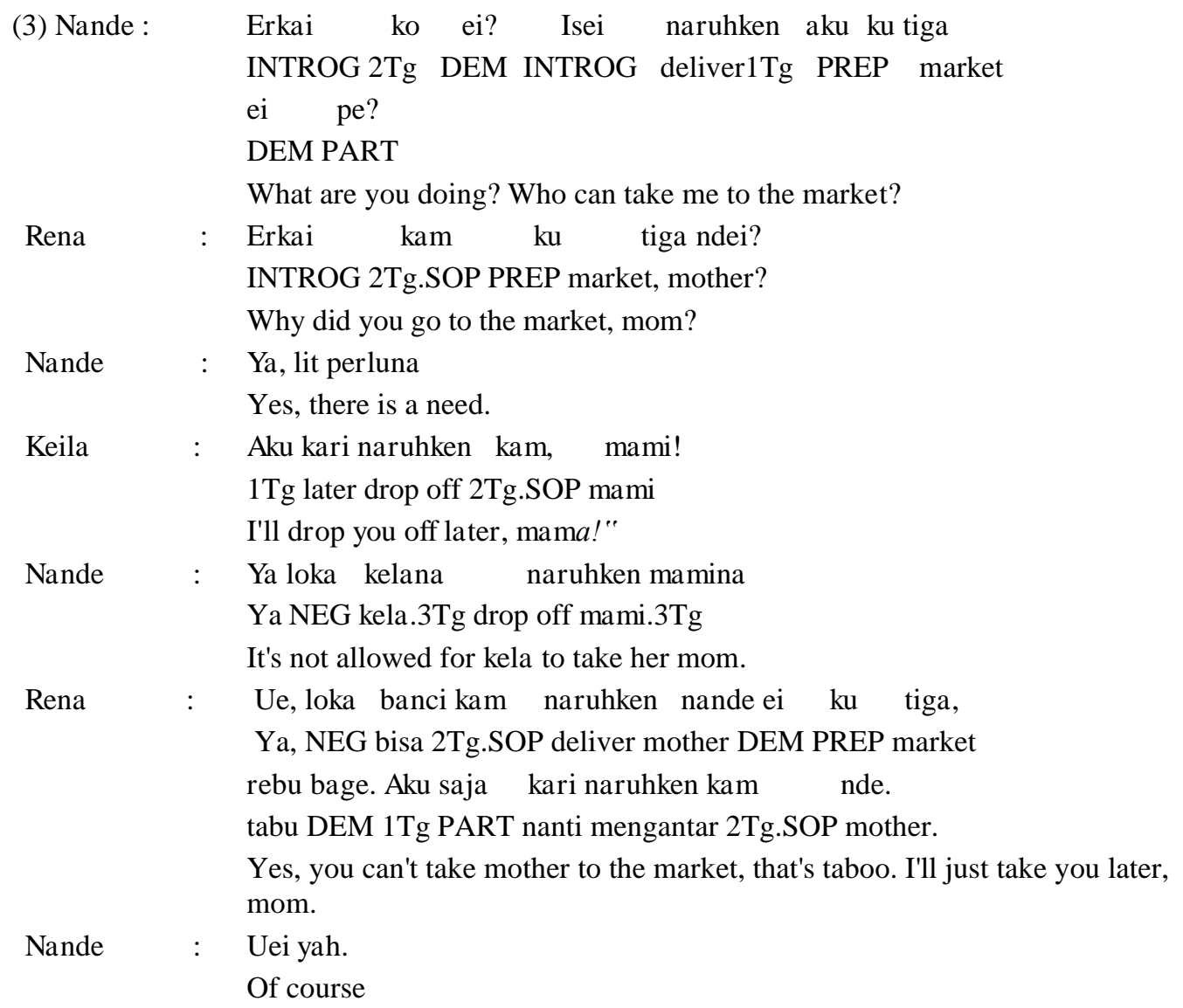

Even though Keila used the polite words "kam" to mami, she was still considered a violation of language etiquette in her culture. This prohibition could also be seen in Mami's response to Keila's words by saying "Yes, loka kelana naruhken Mamina." "You can't let kela bring her mama."Mami pointed out that she still adhered to the language rules, as a mother-in-law, she was not allowed to speak directly to her daughter-inlaw, so when Keila offered to take her, Mami refused.

There were other rebu in Karo language, such as:

a. Rebu shake hands (Rebu Rebu La banci Sisalamen)

The meaning of Rebu in this case was the prohibition of Mother-in-law (Mami) and son-in-law (Kela) from touching body parts. This was done to avoid negative things. When this happened, many people ridiculed and ostracized. Mother-in-law (Mami) and son-in-law (Kela) could touch if something happened that required physical contact such as illness seriously. Mother-in-law (Mami) could touch her daughter-inlaw (Kela) or vice versa by apologizing by saying "Sentabi" first. People understood this because a motherin-law (Mami) and daughter-in-law (Kela) provided a help due to a serious illness. 
b. Rebu face to face (Rebu Sia-alan)

Mother-in-law (Mami) and daughter-in-law (Kela) were not allowed to sit face-to-face because of things made a negative impression. During communication, the mother-in-law (Mami) or daughter-in-law (Kela) must keep your head down and not face to face. For example, the daughter-in-law (Kela), who knew good manners, would lower her head when she wanted to talk or met his mother-in-law (Mami). The daughter-inlaw (Kela) would not come home or visit the house if the mother-in-law (Mami) was alone at home.

c. Rebu one seat (Rebu sada Amak)

Mother-in-law (Mami) and daughter-in-law (Kela) were not allowed to sit on the same mat without someone who sat between them as an intermediary. In Karo language, the mat was called Amak.

\section{d. Rebu walking (Rebu Perdalan)}

Perdalan Sumbang meant "to walk" in an immodest manner or act, such as kicking and waving. Excessive steps and hand movements when walking could cause hatred and a negative impression on many people. For example, son-in-law (Kela) saw mother-in-law (Mami) on her way to the same place as her. To avoid negative things, the daughter-in-law (Kela) kept a distance of about 20 meters from the mother-in-law (Mami).

\subsection{The Meaning of Taboo in Kindship of Karo Tribe}

a. The meaning of 'damaging kinship ethics'

Expressions that meant damaging kinship ethics were found in the expressions in the relationship between bengkila and permain, turangku with turangku, and mami with keila. Taboo in this case was called rebu (in Karo). Rebu began with the mukul ritual (a traditional ritual performed at night after the wedding ceremony). The marriage bond was a very sacred bond based on mutual love, so its integrity must be maintained so that there were no disputes that could lead to divorce between the two. One way to keep the household together in Karo culture was to avoid direct expression between the two (rebu). Doing rebu meant destroying kinship ethics.

\begin{tabular}{|c|c|}
\hline (4) Bengkila & $\begin{array}{l}\text { Kuja kam e permen? } \\
\text { INTROG } 2 \text { Tg PART permain } \\
\text { Where are you going, permain? }\end{array}$ \\
\hline Permain & $\begin{array}{l}\text { Ku kede bengkila, kai kin? } \\
\text { PREP market bengkila INTROG PART } \\
\text { To the market bengkila, what's up? }\end{array}$ \\
\hline Bengkila : & $\begin{array}{l}\text { Tukur sitik isapku Surya da! } \\
\text { Buy PART cigarettes.1Tg Surya PART } \\
\text { Please buy Surya's cigarettes, okay? }\end{array}$ \\
\hline Permain : & $\begin{array}{l}\text { Isap kai bengkila? } \\
\text { Cigarettes INTROG bengkila } \\
\text { What kind of cigarettes, bengkila? }\end{array}$ \\
\hline Bengkila & $\begin{array}{l}\text { Isap Surya. } \\
\text { Surya's cigarettes. }\end{array}$ \\
\hline
\end{tabular}


The data above showed that the bengkila and permain had both violated the rebu. The language used was direct language without using strategies that were justified by Karo culture. Furthermore, direct communication that was not in accordance with the ethics justified by cultural customs could cause feelings that were more than just the relationship between in-laws and daughter-in-law, it could happen love each other, and this was sure to cause conflict in the two big families.

In addition, speaking without limits could sometimes made people forgot to choose the best word to use. Verbal expressions that were too free often had a bad impact on a family relationship, especially two people who came from two different families. Therefore, breaking the taboo of language in this relationship meant destroying the kinship ethics that should be maintained properly.

b. Meaning of 'degrading culture and ancestors'

People who expressed themselves directly in kinship, showed that they were degrading their culture as well as the ancestors who made the rebu rules. The prohibition had been preserved by the ancestors and the community since time immemorial with various challenges that were not easy for them to overcome. Therefore, people who violated this culture were considered to have degraded the culture and the ancestors.

\section{c. Meaning of 'violate politeness'}

Talking directly in a rebu relationship was considered to violate the etiquette of politeness in the Karo language. Speaking in a sacred relationship, it was proper to have rules that were obligatory according to Karo culture. Verbal expressions that were too free often had repercussions bad for a relationship, especially two people who came from two different families. Therefore, the language taboo in this relationship was a good speech ethic by communicating using the right strategy, namely the mediated strategy, so that both tried to use the chosen languages. Breaking the taboo in this case, could be considered impolite or disrespectful. It was non-negotiable unless something inevitable was happening between them.

\section{d. The meaning of 'severing ties of friendship'}

In addition to the two previous meanings, breaking taboos in kinship relations, could also mean breaking the relationship that had been tied to marriage. This could be happened if the possibility of loving or hating each other arises as a result of direct communication between bengkila with permain, turangku with turangku, and mami with keila. Mutual love between bengkila and permain in the sense of love that was more than just the relationship between mother-in-law and daughter-in-law, would certainly cause conflict between bengkila and her son, and between permain and her husband. This condition was to cause a split in their two big families. This could be happened in two other kinship relationships.

\section{Conclusion}

There were several contexts of using taboo language in the Karo community. The context included the family context, the speaker and listener of the conversation, the setting or place of the conversation, the time of the conversation, the topic or event being discussed, the atmosphere or situation of the conversation, and the purpose or intent of the conversation. the Karo ancestors made a boundary not only in attitude but also limits in speaking, namely rebu. Limitations, namely the taboo rules were intended to create harmony, peace, comfort in life that started from the scope of the smallest family that came from two large families who tied with a very sacred marriage rope. The peace of this small scope considered to be the forerunner of peace for all society in larger scope. However, on the other hand, those taboo rules were not just made up to avoid the occurrence of illicit relationships as mentioned above, but rather to the collective awareness of the community to maintain speech and the attitude of the community to stay awake, in order to continue to prioritize 
politeness in expression. Thus, the taboo rule was considered an attempt collective awareness of the community to foster an attitude of courtesy for every member of society so that peace and prosperity could be realized.

This research was similar with Haidir \& Mulyadi (2019) who stated that there were some explicit and implicit taboo words. Implicit taboo words meant prohibitions without attached the context Explicit taboo words meant the use of taboo words in contextual meaning depending on the situation of conversation was required. Rahmayani \& Fitrawati (2018) who stated that taboo words in the sophisticated era had different functions. The use o taboo could determine the intimacy between the speaker and the hearer in a particular conversation.

The writers suggested the Karo people and people from other tribes in general who wanted to communicate in Karo, should understand the word or what verbal expression you want to express. It was recommended to avoid violating the taboo language. The future research of Karo taboo was expected to enrich the treasures and diversity of research in the field of linguistics, especially cultural linguistics or sociolinguistic, known its existence was still rare. Future research should determine the differences of taboo based on speech act to secure individual environment in order to avoid uncertainty. The realization of speech act in taboo could avoid destruction. Those who did not respect the taboos of a culture endanger the cultural survival, growth, or identity. Therefore, disregarding the taboos produced self-destruction and/or destruction. It will offer us valuable resources and guidance for the teaching of sociopragmatics and will better equip Karonese people or foreign people with necessary skill to succeed in intercultural communication.

\section{References}

Allan, K. (2010). Concise Encyclopedia of Semantics. London: Elsevier.

Allan, K. (2019). The Oxford Handbook of Taboo Words and Language. Oxford: Oxford University.

Aveyard, H. (2018). Doing a Literature Review in Health and Social Care: A Practical Guide. New York: Open University Press.

Aveyard, H. (2018). Doing a Literature Review in Health and Social Care: A Practical Guide. New York: Open University Press.

Bauman, R., \& Sherzer, J. (1989). Explorations in the Ethnography of Speaking. Cambridge: Cambridge University.

Birx, H. J. (2006). Encyclopedia of Anthropology: Volume 1. London: Sage Publication.

Brooks, J., \& Arnold, N. (2013). Confronting Racism in Higher Education. New York: Information Age Publishing.

Brooks, J., \& Arnold, N. (2013). Confronting Racism in Higher Education. New York: Information Age Publishing.

Chaudary, A. Y. (2011). The Impact of Television Advertising on Children. New York: Lulu.

Congress, E. P., \& Chang-Muy, F. (2008). Social Work with Immigrants and Refugees: Legal Issues, Clinical Skills and Advocacy. New York: Springer Publishing.

Daymon, C., \& Holloway, I. (2010). Qualitative Research Methods in Public Relations and Marketing Communications. Oxon: Routledge.

German, K. M., Gronbeck, B. C., Ehninger, D., \& Monroe, A. (2016). Principles of Public Speaking. London: Routledge.

Gonzalez, M. (2004). Pragmatic Markers in Oral Narrative: The Case of English and Catalan. Amsterdam: John Benjamin Publishing. 
Haidir, H., \& Mulyadi. (2019). Taboo Language in Malay Panai Language of Labuhan Bilik Dialect, Language Literacy: Journal of Linguistics, Literature, and Language Teaching, 3(1), 101-114.

Halliday, M.A.K dan Ruqaiya Hasan. (1985). Context and Text Language: Aspects of Language in a Social Semiotic View. In Tou, A. (1994). Yogyakarta: UGM Press.

Heinrich, P., \& Ohara, Y. (2019). Routledge Handbook of Japanese Sociolinguistics. Oxon: Routledge.

Hernandez, L. (2009). Crossing Cultural Boundaries: Taboo, Bodies and Identities. United Kingdom: Cambridge Scholars.

Hughes, G. (2015). An Encyclopedia of Swearing. London: Routledge.

Kazeroony, H. H., Stachowicz-Stanusch, A., \& Amann, W. (2019). Advancing African Knowledge Management and Education. New York: Information Age Publishing.

Laksana, I. K. D. (2009). Language Taboo: One Way to Understand Balinese Culture. Denpasar: Udayana University Press.

Mani, R., \& Weiss, T. G. (2013). Responsibility to Protect: Cultural Perspectives in the Global South. London: Routledge.

Marini, I. (2018). The Psychological and Social Impact of Illness and Disability. New York: Springer.

Mhaiske, V. M., Patil, V. K., \& Narkhede, S. (2016). Forest Tribology And Anthropology. New Delhi: Scientific Publishers.

Qanbar, N. (2011). A Sociolinguistic Study of the Linguistic Taboos in the Yemeni Society. http://www.mjal.org/removedprofiles/2013/8.A\%20Sociolinguistic\%20Stu dy\%20of\%20The\%20linguistic\%20Taboos\%20in\%20the\%20Yemeni\%20 Society(1).pdf

Rahmayani, D., \& Fitrawati. (2018). Analysis Types and Functions of Taboo Words in The Wolf of Wall Street Movie, E-Journal of English Language and Literature, 7(3), 336-345.

Rossi, I. (1974). Language and Social Behavior. Harmondsworth: Penguin Books.

Wardhaugh, R. (2009). An Introduction to Sociolinguistics. United Kingdom: Blackwell Publishing.

Zyngier, S., \& Chesnovoka, A. (2007). Acting and Connecting: Cultural Approaches to Language and Literature. Berlin: Lit Verlag. 